\title{
26 Research Square \\ Erosive Effect of Acidic Beverages On Dental Filling Materials Surface (In Vitro Study)
}

\author{
Palacký University, Olomouc

\section{Barbora Novotná} \\ Palacký University, Olomouc

\section{Pavel Holík} \\ Palacký University, Olomouc

\section{Iva Voborná} \\ Palacký University, Olomouc \\ Jana Zapletalová \\ Palacký University, Olomouc
}

Yuliya Morozova ( $\nabla$ yulia.morozova@upol.cz )

\section{Research Article}

Keywords: Erosive tooth wear, influence, Erosive factors, glassionomer

Posted Date: July 22nd, 2021

DOI: https://doi.org/10.21203/rs.3.rs-720783/v1

License: (c) (1) This work is licensed under a Creative Commons Attribution 4.0 International License. Read Full License 


\section{Abstract}

Erosive tooth wear, that is characterized like irreversible loss of hard dental tissues due to influence of external and internal acids of nonbacterial origin, is one of the most common damage of a tooth surface. Erosive factors also affect the surface of dental reconstruction materials that ideally should be resistant against them. Dental filling materials designed for this purpose must be able to withstand these effects in a comparable or even better way than enamel. In our in vitro study we investigated using the nanoindentation the hardness of currently available dental filling materials (dental composite resin, self curing and dual cures glassionomer cement, dental amalgam) before and after erosive attacks (exposure to Coca Cola for 5 min and 14 days) and consequently compare it with them of human dental enamel. Furtermore we analised the surface topography of the samples before and after acidic exposure by confocal laser scanning microscope. In our experiments the filling materials were affected by the acidic environment only minimally in comparison with hard dental tissues. We confirmed the fact that dental amalgam is still the most mechanically and chemically resistant filling material. Both GIC materials showed the worst resistance against acidic conditions and higher surface roughness even before exposure. We also declared excellent withstanding of resin composite materials against acidic conditions that was even better than natural enamel. Furthermore by CLSM was detected almost unaltered surface of these filling materials. This fact as well as adhesive properties of resin composites allow to assume that this material could be the most suitable material for dental erosion reconstruction.

\section{Introduction}

Erosion is the loss of hard dental tissues caused by the action of acids of nonbacterial origin on the tooth surface without dental plaque. The definition of dental erosion dates from 1949 and the authors are Zipkin and McClure [1, 2]. Acids can be of either exogenous (e.g. dietary acids from fruit, juices, acidic dressings; acids in medicaments, environment or occupation) or endogenous (stomach acids) origin.

Erosive lesions can be divided according to their origin into four groups [1, 2, 3]:

1. Dietary erosions, that are occurred in individuals with frequent and excessive consumption of acidic foods (fruit, fruit juices, carbonated acidic drinks, sport/energy drinks, low pH beer, herbal teas; vinegar, pickles) or due to intake of acidic medicaments (vitamin C, iron remedies, some antiasthmatic medicaments, non-encapsulated hydrochlorid acid replacement, acetylsalicylic acid) especially in form of chewing or effervescent tablets.

2. Regurgitation erosions that are typical symptoms of conditions with frequent reflux (e.g. gastroesophageal relfux disease) or vomiting (e.g. in nutrition disorders, diabetes mellitus, chronic alcoholism etc.)

3. Occupational or industrial erosions, their main reason is acids in employment (chemical industries, wine tasting) or in the environment

4. Idiopathic erosions, which are occurred in people with increased content of citric acid in saliva 
The effect of acids on dental tissues has been described and investigated many times in laboratory and clinical conditions $[3,4]$. The main inorganic component of dentin and enamel is carbonate hydroxyapatite. The acids occur in the oral cavity in dissociated form in the form of the trihydrogen cation $\mathrm{H}^{3+}$ and the anion of the acid residue. The trihydrogen cation reacts with the phosphate and carbonate anions from mineral lattice of hard dental tissues [5]. In addition, anions of organic acids (e. g. citric acid) can form complex compounds with calcium hydroxyapatite. These anions are known as chelating agents [6]. The result of these processes is the release of minerals from the crystal lattice of hard dental tissues, which leads to a reduction in the hardness of the tooth surface that is prone to further abrasive wear [7].

The most frequent type of dental erosions are dietary erosions that could be caused among other things by frequent intake of acidic beverages (e.g. fruit juices, carbonated soft drinks or acidic mineral waters). Their consumption leads to significant decrease of $\mathrm{pH}$ in oral cavity up to 15 minutes [8]. However, these acids act not only on hard dental tissues, but also on all artificial reconstruction materials found in the mouth.

One of the most famous drinks in the world is Coca-Cola. Due to its unchanged composition worldwide, this beverage is also mostly often used in different investigations aimed to dental erosion formation as well as teeth resistance to erosion [8].

It is possible to assume a situation where an erosive defect of the tooth causes exposure of dentin and thus there may be irritation of the dental pulp. This defect needs to be filled with one of the filling materials and thus it creates a barrier between the exposed dentin and the environment of the oral cavity. However, this material will also be exposed to acidic pH unless the patient's dietary habits are modified [9].

Acid resistance is an essential attribute of any filling material. Different resistance of different types of fillings can be assumed [10]. From amalgam, which is assumed to be completely inert to acids, through composite materials, which depend on the matrix and filler used, to glass ionomer cements, which due to their remineralization potential may be prone to rapid demineralization $[11,12]$.

The aim of our in vitro study was to investigate using nanoindentation the effect of dietary acids on the hardness of samples of common currently available dental filling materials and compare them with enamel hardness exposed to the same dietary acids. Other aim was to investigate their surface topography after erosive changes using confocal laser scanning microscope (CLSM).

\section{Materials And Methods}

In our research we used the following categories of filling materials:

- nanohybride dental composite (Filtek Ultimate, 3M ESPE, USA)

- nanohybride dental flowable composite (Filtek Ultimate Flow, 3M ESPE, USA) 
- self curing glass ionomer cement (Omnifill C, Omnident, Germany)

- dual cured resin modified glass ionomer cement (Harvard lonoresin Fill, Harvard, Germany)

- non-gamma-2 capsulated dental amalgam (GS-80, SDI, Australia)

From each material using silicone matrix a disc-shaped sample with a diameter of $5 \mathrm{~mm}$ and a thickness of $3 \mathrm{~mm}$ was prepared according to manufacturer rules. After setting the samples were polished with OptiDisc (KerrHawe, Switzerland) Coarse/Medium with a grain size of $40 \mu \mathrm{m}$, Fine with a grain size of 20 $\mu \mathrm{m}$ and Extra Fine with a grain size of $10 \mu \mathrm{m}$ in the blue micromotor without water cooling. Total number of samples in each material type was 30 . In the same way 30 enamel samples were prepared [13].

The samples were exposed to Coca Cola of room temperature (Coca-Cola HBC, Czech Republic, composition: water, sugar, carbonic acid, dye E150d, phosphoric acid, aroma, caffeine; pH 2.6) [14] for 5 minutes and for clarity of the erosion process also for 14 days. A control sample of each material as well as enamel was kept in distilled water for the same time.

The samples were then removed and hardness measurements were performed by nanoindentation (nanoindenter NanoTest NT 600, Micromaterials, Great Britain). In our experiments we used an indentation force of $10 \mathrm{mN}$ applied to a calibrated Berkovich indenter, with loading and subsequent unloading at a speed of $0.5 \mathrm{mN} / \mathrm{s}$. The period during which the sample was exposed to the maximum indentation load was 5 seconds. Six measurements were performed on each sample. The individual impressions were placed in a linear matrix, the distance between the impressions was $30 \mu \mathrm{m}$. The impression hardness (nanoindentation hardness) was determined from the experimental indentation curves using the method proposed by Oliver and Pharr [15]. Only standard shape curves were analyzed. The characteristic mean microhardness values of the respective sample were always calculated from at least four independent measurements and are given in GPa [13]. The results of nanoindentation measurement of filling materials samples were statistically processed using Wilcoxon paired and Kruskal-Wallis tests at significance level 0.05. For statistical analysis software IBM SPSS Statistics version 22 (Armonk, NY: IBM Corp.) was used.

Optical analysis was also performed with a digital light microscope and a confocal laser scanning microscope (LEXT OLS 3100).

\section{Results}

\section{Nanoindentation measurement}

The results of nanoindentation measurements are presented in Tables 1-5.

There was also no significant change in the hardness of the sample of filling material immersed for 5 minutes in Coca-Cola compared to the sample placed in distilled water. Furthermore, no significant difference in the change in hardness was demonstrated between the individual types of filling materials tested (Tables 1-5). 
In the case of long-term exposure ( 14 days), the samples of the enamel and both glass ionomer filling materials (Harvard lonoresin Fill, Omnifill C) were eroded to such an extent that their surface hardness was no longer measurable by nanoindentation. Samples of amalgam and composite materials (Filtek Ultimate, Filtek Ultimate Flow) did not show a significant change in hardness compared to a reference sample of the material placed in water (Tables 1-5). Summary of nanoindentation measurements of filling materials and enamel samples are placed in Table 6.

All tested filling materials showed a significantly smaller change in hardness (t-test, $p<0.0001)$ after 5 minutes of Coca-Cola exposure than that of the enamel (Table 7).

\section{Optical analysis of individual materials}

\section{Nanohybrid resin composite Filtek Ultimate}

Figure 1 demonstrates macroscopic picture of sample surface made from nanohybrid resin composite Filtek Ultimate before (Figure 1a) and after (Figure 1b) exposure to Coca Cola for 14 days. No difference between the samples was observed macroscopically, both retaining their gloss, smooth surface and hardness.

The microscopic picture of the samples is demonstrated on Fig. 2. Using CLSM it can be confirmed that the surface homogeneity of the composite filling is excellent and the predilection sites of higher erosive damage are only small and due to the composition of the material it can be expected that the erosion will be only slight.

After exposure to Coca Cola (Fig. 2b) microscopic erosive defects are already slightly visible, several larger pieces of particles or rather clusters of these particles have been released, but they are still not visible macroscopically as in other samples. Furthermore, it should be noted that an equally long exposure of an intact tooth to Coca Cola would lead to significantly larger and macroscopically noticeable defects of hard dental tissues.

\section{Flowable nynohybrid resin composite Filtek Ultimate Flow}

In Fig. 3a it is visible that material before immersion to beverage had a macroscopically very smooth surface. Exposure to Coca Cola caused a loss of gloss on some parts of the sample surface (Fig. 3b).

Microscopic analysis (Fig. 4) demonstrates the surface erosion that is already clearly after 14 days exposure, but does not interfere with the deeper structures of the material. Some larger clusters of filler particles are also missing. We observe the so-called delamination of layers, where the individual layers of the filler are lost and deeper layers are revealed, but this do not cause the hardness reduction [16].

\section{Self curing glass ionomer cement Omnifill $C$}

Macroscopically the material sample even before the exposure to acidic environment had small surface defects (Fig. 5a). Furthermore, the surface is less glossy than the dual cured GIC, as well as greater roughness can also be observed. However, we did not observe a different distribution of the filler, the sample seems more homogeneous. Deep erosive defects are visible on the surface of the eroded sample 
(Fig. 5b). However, in contrast to other samples, macroscopic infractions are not visible. The surface is very uneven and very prone to mechanical wear, even to simple two-body abrasion by another significantly less hard surface.

Even at the microscopic level (Fig. 6a), we observe a higher homogeneity and a low incidence of surface irregularities, which, however, can only be due to the focus of the image. After exposure for 14 days in Coca Cola (Fig. 6b) deep, sharply demarcated defects appear in which the dye from the beverage settles and the entire surface shows minimal hardness.

\section{Dual cured resin modified glass ionomer cement Harvard lonoresin Fill}

Macroscopic image (Fig. 7) of the material sample demonstrates great difference before (Fig. 7a) and after exposure (Fig. 7b). Brown lines on the exposed sample are visible even without magnification (Fig. 7b). The erosive process, although it took place over the entire surface and caused a slight increase in roughness and thus dimming of the polished surface, took place much more intensively on the predilection lines. The etched surface roughness into which the acidic beverage has flowed in and the dye has settled can now be seen.

An inhomogeneous surface can also be observed in the CLSM image of the sample exposed only to water, however, no infractions are visible, as it may have seemed from the previous image, no scratches are visible in the surface, rather uneven solidification of the material caused places with different filler saturation (Fig. 8a).

After 14 days in Coca Cola in microscope image the sample surface shows numerous defects that extend deep below the surface of the filling (Fig. 8b). Furthermore, a layer of highly eroded soft material covering the surface was recorded, which, among other things, made it impossible to measure the hardness by nanoindentation.

\section{Non-gamma-2 dental capsulated amalgam GS- 80}

The images of the amalgam samples are present amalgam fillings for the completeness of the analysis. The assumption, which is also confirmed, was that amalgam as filling material has not been affected in any way by the acidic environment. No macroscopic differences can be observed between the control sample (Fig. 9a) and the sample exposed to acidic pH (Fig. 9b).

In CLSM the differences between the samples are only minimal (Fig. 10a, Fig. 10b). They can be attributed to the different focus of the microscope. No defect that it could potentially compromise the filling as such or even be macroscopically visible was noted. CLSM images are taken at a higher magnification for higher detection of small defects.

\section{Discussion}

It is known that during the last decades the consumption of acidic beverages like carbonated soft drinks, fruit juices or sport drinks is dramatically increased [2]. Frequent and excessive intake of acidic foods and 
beverages could lead to dental erosions. In our in vitro study we used Coca Cola like one of the most popular soft drink, their intake is really wise around the world. However the erosive potential of acidic foods and drinks depends not only on low value of $\mathrm{pH}$, but also other chemical properties, like titratable acidity, type and dissociation constant of the acid, content of mineral components $\left(\mathrm{Ca}^{2+}, \mathrm{F}^{-}, \mathrm{PO}_{4}{ }^{3-}\right)$ as well as physical properties, like temperature, adhesion, amount, frequency and time during that the acidic food is present in oral cavity $[2,3,5,6]$. Finally in in vivo situation further modifying factors (biological and behavioural) play role in erosion formation. It could be some limit for in vitro studies because in in vitro conditions it is impossible to simulate and investigate all of these factors. On the other hand in vitro study provides an excellent possibility for standardization and more precious realization of investigation of acidic drinks erosive effect.

According to our observations, the filling materials were affected by the acidic environment only minimally in comparison with hard dental tissues. Due to the calcium content glass ionomer cements were prone to surface erosion even after a relatively short exposure, but compared to dental tissues, it cannot be said that surface erosion will cause filling failure [17]. Rather, it will be a precursor to other related damage, such as mechanical wear, scratches, and especially predilection sites of fractures. Clinical observations show that the GIC filling most often fails under mechanical fracture stress [18]. The results of our measurements of GIC samples are in agreement with other studies dealing with similar issue $[17,19]$.

According to our nanoindenatation experiment and surface optical analysis results amalgam had proven to be the best acid-resistant material. No signs of surface erosion were observed. Thus, compared to enamel, it can be assumed and clinical observations confirm that amalgam will resist acids better than tooth alone or other filling material [20]. However, due to the complexity of the amalgam for cavity shape and retention and aesthetically poor properties, it is not and will not be an option for solving erosive defects [21]. Furthermore due to the potential toxic effects of mercury this material is restricted to be used in children younger than 6 years (FDA recommendation, July 2010) [22]. In EU starting from July 2018 it is not used in pregnant, breastfeeding women, primary teeth reconstructions as well as children younger than 15 years [23].

Composite fillings withstood an acidic environment in our experiments better than enamel. There were only microscopic changes in the surface and desquamation of the surface particles of the filler. Even prolonged exposure to Coca Cola for 14 days did not lead to macroscopic changes of nanohybrid composite resin samples. Furthermore, it should be noted that an equally long exposure of an intact tooth to Coca Cola would lead to significantly larger and macroscopically noticeable defects of hard dental tissues.

With respect to flowable composite resin after the acidic exposure some macroscopic changes (gloss loss) were apparent. CLSM analysis demonstrated loss of some larger clusters of filler particles as well as so-called delamination of layers [16]. This mechanism of erosion, where the individual layers of the filler peel off, reveals deeper layers that are topographically uneven, but do not have reduced hardness. 
Conversely, in hybrid materials, where the distribution of the filler is not homogeneous, it is possible to measure an area with a higher concentration of filler particles under the desquamated layer and thus harder in the indentation measurement. These results can be found in the study of Hong-Yi Fan et al. [24].

Furthermore, the composition of composite materials has a certain effect on the erosion of the surface of composites. Organic acids dissolve Bis-GMA polymers more easily and filler particles are released. Depending on the type of binder and its percentage relative to the filler, the speed of the erosive process will change $[25,26]$. In terms of surface and its resistance to acids, however, the composite material performed well, as evidenced by other studies [17, 24, 27-29]. Due to the adhesion of the material even on small erosive defects without the necessity of retention cavity preparation, this type of material appears to be an ideal choice for the treatment of erosive defects [9]. They can probably also be used preventively as a protective layer that protects hard dental tissues from acids [30]. However, the identification and elimination of the cause remains the primary and most important in the treatment of erosion [31].

\section{Conclusion}

Our investigation confirmed the fact that dental amalgam is still the most mechanically and chemically resistant filling material. The exposure in dietary acids did not lead any change of hardness and surface structure. Both GIC materials showed the worst resistance against acidic conditions and higher surface roughness even before exposure. By contrast we declared excellent withstanding of resin composite materials against acidic conditions that was even better than natural enamel. Furthermore by CLSM was detected almost unaltered surface of these filling materials. This fact as well as adhesive properties of resin composites allow to assume that this material could be the most suitable material for dental erosion reconstruction.

\section{Declarations}

The author(s) declare no competing interests.

\section{References}

1. Zipkin, I.\& McClure, F.J. Salivary citrate and dental erosion; procedure for determining citric acid in saliva; dental erosion and citric acid in saliva. J Dent Res. 1949 Dec;28(6):613-626.

2. Lussi, A. \& Jaeggi, T. Erosion-diagnosis and risk factors. Clin Oral Investig. 2008 Mar;12 Suppl 1(Suppl 1):S5-13.

3. Saads Carvalho, T. \& Lussi, A. Acidic beverages and foods associated with dental erosion and erosive tooth wear in The impact of nutrition and diet on oral health (ed. Zohoori, F.V. \& Duckworth, R.M.) 91-98 (Basel, Karger, 2020). 
4. Joshi, M., Joshi, N., Kathariya, R., Angadi, P. \& Raikar, S. Techniques to evaluate dental erosion: A systematic review of literature. J Clin Diagn Res. 2016;10(10):ZE01-ZE07.

5. Shellis, R.P., Featherstone, J.D. \& Lussi, A. Understanding the chemistry of dental erosion in Erosive tooth wear (ed. Lussi, A.) 163-179 (Basel, Karger, 2014).

6. Lussi, A., Addy, M. \& Angmar-Mansson, B. Dental erosion from diagnosis to therapy (Basel, Karger, 2006).

7. Rajeev, G. \& Lewis, A.J. A time based objective evaluation of the erosive effects of various beverages on enamel and cementum of deciduous and permanent teeth. J Clin Exp Dent. 2020, 12, iss. 1.

8. Hans, R., Thomas, S., Garla, B., Dagli, R.J. \& Hans, M.K. Effect of various sugary beverages on salivary pH, flow rate, and oral clearance rate amongst adults. Scientifica (Cairo). 2016, vol. 2016.

9. Loomans, B. et al. Severe tooth wear: European consensus statement on management guidelines. $J$ Adhes Dent. 2017, vol. 19, iss. 2, 111-119

10. Ahmed, M.E. Surface hardness assessment of tooth substrates and different esthetic restorative materials after immersion in different acidic media. Int J Dent \& Oral Heal. 2018, vol. 4, iss. 11, 178-183.

11. Aliping-McKenzie, M., Linden, R.W. \& Nicholson J.W. The effect of Coca-Cola and fruit juices on the surface hardness of glass-ionomers and 'compomers'. J Oral Rehabil. 2004, vol. 34, iss. 11, 1046-1052.

12. Ozdemir-Ozenen, D., Sungurtekin-Ekci, E. \& Ozenen, G. Effect of common daily acidic beverages on the surface roughness of glass ionomer-based dental restorative biomaterials. Glass Phys Chem. 2019, vol. 45, 496-502.

13. Morozova, J., Zapletalová, Z., Čtvrtlík, R. \& Ranc V. Effect of selected acidic foodstuffs and beverages on enamel mechanical properties of human extracted teeth and their role in dental erosion origin. Česká stomat /Prakt zub lék. 2012, vol. 112, iss. 3, 77-87.

14. Attin, T. Weis, K., Becker, K., Buchalla, W. \& Wiegand, A. Impact of modified acidic soft drinks on enamel erosion. Oral Diseases. 2005, vol. 11, 7-12.

15. Oliver, W.C. \& Pharr, G.M. An improved technique for determining hardness and elastic modulus using load and displacement sensing indentation experiments. Journal of Materials Research. 1992, vol. 7, iss. 6, 1564-1583.

16. Onat, A. Mechanical and dry sliding wear properties of silicon carbide particulate reinforced aluminium-copper alloy matrix composites produced by direct squeeze casting method. Journal of Alloys and Compounds. 2010, vol. 489, 119-124. 
17. Wongkhantee, S., Patanapiradej, V., Maneenut, C. \& Tantbirojn. D. Effect of acidic food and drinks on surface hardness of enamel, dentine, and tooth-coloured filling materials. J Dent. 2006, vol. 34, iss. 3, 214-220.

18. Heck, K. et al. Six-year results of a randomized controlled clinical trial of two glass ionomer cements in class II cavities. J Dent. 2020, vol. 97.

19. Hengtrakool, C., Kukiattrakoon, B. \& Kedjarune-Leggat, U. Effect of naturally acidic agents on microhardness and surface micromorphology of restorative materials. Eur J Dent. 2011 Jan;5(1):89-100.

20. Honório, H.M. et al. Effect of prolonged erosive pH cycling on different restorative materials. J Oral Rehabil. 2008, vol. 35, 947-953.

21. Patki, B. Direct permanent restoratives-amalgam vs composite. Journal of Evolution of Medical and Dental Sciences. 2013, vol. 2, iss. 46, 8912-8919.

22. US Department of Health and Human Services. Final Rule Federal Register 75: Issue 112 (Friday, June 11, 2010) https://www.govinfo.gov/content/pkg/FR-2010-06-11/pdf/2010-13987.pdf\#page=2

23. Regulation (EU) 2017/852 of the European Parliament and of the Council of 17 May 2017 on mercury, and repealing Regulation (EC) No 1102/2008 https://eur-lex.europa.eu/eli/reg/2017/852/oj

24. Hong-Yi, F., Xue-Qi, G., Yang, L., Zhuo-Li, Z., Hai-Yang, Y. The nanomechanical and tribological properties of restorative dental composites after exposure in different types of media. Journal of Nanomaterials. 2014, vol. 2014, 1-9.

25. Söderholm, K.J. et al. Clinical wear performance of eight experimental dental composites over three years determined by two measuring methods. Eur J Oral Sci. 2001, vol. 109, 273-281.

26. Prakki, A., Cilli, R., Mondelli, R.F., Kalachandra, S. \& Pereira, J.C. Influence of pH environment on polymer based dental material properties. J Dent. 2005 Feb;33(2):91-98.

27. Attin, T. \& Wegehaupt, F.J. Impact of erosive conditions on tooth-colored restorative materials. Dental Materials. 2014, vol. 30, iss. 1, 43-49.

28. Münchow, E.A. et al. Effect of acidic solutions on the surface degradation of a micro-hybrid composite resin. Braz Dent J. 2014;25(4):321-326.

29. Badra, V.V., Faraoni, J.J., Ramos, R.P. \& Palma-Dibb, R.G. Influence of different beverages on the microhardness and surface roughness of resin composites. Oper Dent. 2005 Mar-Apr;30(2):213-219.

30. Zhao, X., Pan, J., Malmstrom, H.S. \& Yan-Fang, R. Protective effects of resin sealant and flowable composite coatings against erosive and abrasive wear of dental hard tissues. $J$ Dent. vol. $49,68-74$. 
31. Yip, K.H.K., Smales. R.J. \& Kaidonis, J.A. Tooth erosion prevention and treatment 88-103 (Jaypee Brothers Medical Publishers, 2008).

\section{Tables}

Table 1

Descriptive statistics of nanoindentation measurements of nanohybrid dental composite resin Filtek Ultimate (hardness, GPa)

\begin{tabular}{|c|c|c|c|c|c|c|}
\hline & Mean & SD & Median & Minimum & Maximum & $\begin{array}{l}\text { p-value } \\
\text { (Wilcoxon } \\
\text { paired } \\
\text { test) }\end{array}$ \\
\hline Distilled water & 0.90 & 0.22 & 0.90 & 0.50 & 1.20 & - \\
\hline Coca Cola (exposure 5 min) & 0.91 & 0.20 & 0.90 & 0.60 & 1.30 & - \\
\hline Coca Cola (exposure 14 days) & 0.87 & 0.26 & 0.85 & 0.50 & 1.30 & - \\
\hline $\begin{array}{l}\text { Nanohardness change (Coca } \\
\text { Cola } 5 \text { min vs. distilled water) }\end{array}$ & 0.01 & 0.33 & -0.05 & -0.40 & 0.60 & 1 \\
\hline $\begin{array}{l}\text { Nanohardness change (Coca } \\
\text { Cola } 14 \text { days vs. distilled water) }\end{array}$ & -0.03 & 0.41 & -0.20 & -0.60 & 0.50 & 1 \\
\hline $\begin{array}{l}\text { Nanohardness change (Coca } \\
\text { Cola } 14 \text { days vs. Coca Cola } 5 \\
\text { min) }\end{array}$ & -0.04 & 0.39 & -0.10 & -0.60 & 0.70 & 1 \\
\hline
\end{tabular}


Table 2

Descriptive statistics of nanoindentation measurements of flowable nanohybrid dental composite resin Filtek Ultimate Flow (hardness, GPa)

\begin{tabular}{|c|c|c|c|c|c|c|}
\hline & Mean & SD & Median & Minimum & Maximum & $\begin{array}{l}\text { p-value } \\
\text { (Wilcoxon } \\
\text { paired } \\
\text { test) }\end{array}$ \\
\hline Distilled water & 0.65 & 0.16 & 0.65 & 0.40 & 0.90 & - \\
\hline Coca Cola (exposure $5 \mathrm{~min}$ ) & 0.72 & 0.21 & 0.80 & 0.40 & 1.00 & - \\
\hline Coca Cola (exposure 14 days) & 0.60 & 0.16 & 0.65 & 0.40 & 0.80 & - \\
\hline $\begin{array}{l}\text { Nanohardness change (Coca } \\
\text { Cola } 5 \text { min vs. distilled water) }\end{array}$ & 0.07 & 0.29 & 0.05 & -0.30 & 0.60 & 1 \\
\hline $\begin{array}{l}\text { Nanohardness change (Coca } \\
\text { Cola } 14 \text { days vs. distilled water) }\end{array}$ & -0.05 & 0.18 & -0.05 & -0.30 & 0.20 & 1 \\
\hline $\begin{array}{l}\text { Nanohardness change (Coca } \\
\text { Cola } 14 \text { days vs. Coca Cola } 5 \\
\text { min) }\end{array}$ & -0.12 & 0.26 & -0.05 & -0.60 & 0.20 & 0.609 \\
\hline
\end{tabular}

Table 3

Descriptive statistics of nanoindentation measurements of self curing glass ionomer cement Omnifill C (hardness, GPa)

\begin{tabular}{|c|c|c|c|c|c|c|}
\hline & Mean & SD & Median & Minimum & Maximum & $\begin{array}{l}\text { p-value } \\
\text { (Wilcoxon } \\
\text { paired } \\
\text { test) }\end{array}$ \\
\hline Distilled water & 1.01 & 0.45 & 1.10 & 0.40 & 1.60 & - \\
\hline Coca Cola (exposure 5 min) & 0.96 & 0.49 & 0.80 & 0.40 & 1.60 & - \\
\hline Coca Cola (exposure 14 days) & - & - & - & - & - & - \\
\hline $\begin{array}{l}\text { Nanohardness change (Coca } \\
\text { Cola } 5 \text { min vs. distilled water) }\end{array}$ & -0.05 & 0.73 & -0.10 & -1.20 & 1.10 & 0.767 \\
\hline $\begin{array}{l}\text { Nanohardness change (Coca } \\
\text { Cola } 14 \text { days vs. distilled water) }\end{array}$ & - & - & - & - & - & - \\
\hline $\begin{array}{l}\text { Nanohardness change (Coca } \\
\text { Cola } 14 \text { days vs. Coca Cola } 5 \\
\text { min) }\end{array}$ & - & - & - & - & - & - \\
\hline
\end{tabular}


Table 4

Descriptive statistics of nanoindentation measurements of dual cured resin modified glass ionomer cement Harvard lonoresin Fill (hardness, GPa)

\begin{tabular}{|c|c|c|c|c|c|c|}
\hline & Mean & SD & Median & Minimum & Maximum & $\begin{array}{l}\text { p-value } \\
\text { (Wilcoxon } \\
\text { paired } \\
\text { test) }\end{array}$ \\
\hline Distilled water & 0.78 & 0.38 & 0.65 & 0.30 & 1.50 & - \\
\hline Coca Cola (exposure 5 min) & 0.73 & 0.40 & 0.55 & 0.30 & 1.40 & - \\
\hline Coca Cola (exposure 14 days) & - & - & - & - & - & - \\
\hline $\begin{array}{l}\text { Nanohardness change (Coca } \\
\text { Cola } 5 \text { min vs. distilled water) }\end{array}$ & -0.05 & 0.48 & -0.15 & -1.00 & 0.80 & 0.644 \\
\hline $\begin{array}{l}\text { Nanohardness change (Coca } \\
\text { Cola } 14 \text { days vs. distilled water) }\end{array}$ & - & - & - & - & - & - \\
\hline $\begin{array}{l}\text { Nanohardness change (Coca } \\
\text { Cola } 14 \text { days vs. Coca Cola } 5 \\
\text { min) }\end{array}$ & - & - & - & - & - & - \\
\hline
\end{tabular}

Table 5

Descriptive statistics of nanoindentation measurements of non-gamma-2 capsulated dental amalgam GS-80 (hardness, GPa)

\begin{tabular}{|c|c|c|c|c|c|c|}
\hline & Mean & SD & Median & Minimum & Maximum & $\begin{array}{l}\text { p-value } \\
\text { (Wilcoxon } \\
\text { paired } \\
\text { test) }\end{array}$ \\
\hline Distilled water & 2.25 & 0.38 & 2.30 & 1.60 & 2.70 & - \\
\hline Coca Cola (exposure 5 min) & 2.23 & 0.28 & 2.25 & 1.80 & 2.60 & - \\
\hline Coca Cola (exposure 14 days) & 2.24 & 0.34 & 2.25 & 1.70 & 2.80 & - \\
\hline $\begin{array}{l}\text { Nanohardness change (Coca } \\
\text { Cola } 5 \text { min vs. distilled water) }\end{array}$ & -0.02 & 0.31 & 0.05 & -0.60 & 0.40 & 1 \\
\hline $\begin{array}{l}\text { Nanohardness change (Coca } \\
\text { Cola } 14 \text { days vs. distilled water) }\end{array}$ & -0.01 & 0.58 & 0.05 & -0.90 & 0.80 & 1 \\
\hline $\begin{array}{l}\text { Nanohardness change (Coca } \\
\text { Cola } 14 \text { days vs. Coca Cola } 5 \\
\text { min) }\end{array}$ & 0.01 & 0.44 & 0.00 & -0.80 & 0.60 & 1 \\
\hline
\end{tabular}


Table 6

Summary of nanohardness measurements of dental filling materials and dental enamel, Kruskal-Wallis test

\begin{tabular}{|c|c|c|c|c|c|c|}
\hline & \multicolumn{2}{|c|}{ Distilled water } & \multicolumn{2}{|c|}{$\begin{array}{l}\text { Coca Cola (exposure } 5 \\
\text { min) }\end{array}$} & \multicolumn{2}{|c|}{$\begin{array}{l}\text { Coca Cola (exposure } 14 \\
\text { days) }\end{array}$} \\
\hline & $\begin{array}{l}\text { Hardness, } \\
\text { GPa }\end{array}$ & $\begin{array}{l}\text { STD. } \\
\text { Deviation, } \\
\text { GPa }\end{array}$ & $\begin{array}{l}\text { Hardness, } \\
\text { GPa }\end{array}$ & $\begin{array}{l}\text { STD. } \\
\text { Deviation, } \\
\text { GPa }\end{array}$ & $\begin{array}{l}\text { Hardness, } \\
\text { GPa }\end{array}$ & $\begin{array}{l}\text { STD. } \\
\text { Deviation, } \\
\text { GPa }\end{array}$ \\
\hline $\begin{array}{l}\text { Harvard } \\
\text { lonoresin Fill }\end{array}$ & 0.78 & 0.36 & 0.73 & 0.38 & $\begin{array}{l}\text { Non- } \\
\text { measurable }\end{array}$ & $\begin{array}{l}\text { Non- } \\
\text { measurable }\end{array}$ \\
\hline Omnifill C & 1.01 & 0.43 & 0.96 & 0.47 & $\begin{array}{l}\text { Non- } \\
\text { measurable }\end{array}$ & $\begin{array}{l}\text { Non- } \\
\text { measurable }\end{array}$ \\
\hline $\begin{array}{l}\text { Filtek } \\
\text { Ultimate }\end{array}$ & 0.9 & 0.19 & 0.91 & 0.19 & 0.87 & 0.25 \\
\hline $\begin{array}{l}\text { Filtek } \\
\text { Ultimate } \\
\text { Flow }\end{array}$ & 0.65 & 0.2 & 0.72 & 0.2 & 0.6 & 0.15 \\
\hline $\begin{array}{l}\text { Dental } \\
\text { amalgam }\end{array}$ & 2.25 & 0.36 & 2.23 & 0.26 & 2.24 & 0.33 \\
\hline Enamel & 4.9 & 0.4 & 4 & 0.5 & $\begin{array}{l}\text { Non- } \\
\text { measurable }\end{array}$ & $\begin{array}{l}\text { Non- } \\
\text { measurable }\end{array}$ \\
\hline
\end{tabular}


Table 7

Comparison of changes in hardness of dental materials and dental enamel (Coca Cola, exposure 5 min vs. distilled water)

\begin{tabular}{|c|c|c|c|c|c|}
\hline & \multicolumn{2}{|c|}{ Distilled water } & \multicolumn{2}{|c|}{ Coca Cola (exposure 5 min) } & \multirow{2}{*}{$\begin{array}{l}\mathrm{p} \text { - } \\
\text { value, } \\
\text { t-test }\end{array}$} \\
\hline & $\begin{array}{l}\text { Hardness, } \\
\text { GPa }\end{array}$ & $\begin{array}{l}\text { STD. Deviation, } \\
\text { GPa }\end{array}$ & $\begin{array}{l}\text { Hardness, } \\
\text { GPa }\end{array}$ & $\begin{array}{l}\text { STD. Deviation, } \\
\text { GPa }\end{array}$ & \\
\hline $\begin{array}{l}\text { Harvard Ionoresin } \\
\text { Fill }\end{array}$ & 0.78 & 0.36 & 0.73 & 0.38 & $<0,0001$ \\
\hline Omnifill C & 1.01 & 0.43 & 0.96 & 0.47 & $<$ \\
\hline Filtek Ultimate & 0.9 & 0.19 & 0.91 & 0.19 & $<0,0001$ \\
\hline $\begin{array}{l}\text { Filtek Ultimate } \\
\text { Flow }\end{array}$ & 0.65 & 0.2 & 0.72 & 0.2 & $<0,0001$ \\
\hline Dental amalgam & 2.25 & 0.36 & 2.23 & 0.26 & $\begin{array}{l}<, 0001 \\
0\end{array}$ \\
\hline Enamel & 4.9 & 0.4 & 4 & 0.5 & \\
\hline
\end{tabular}

\section{Figures}

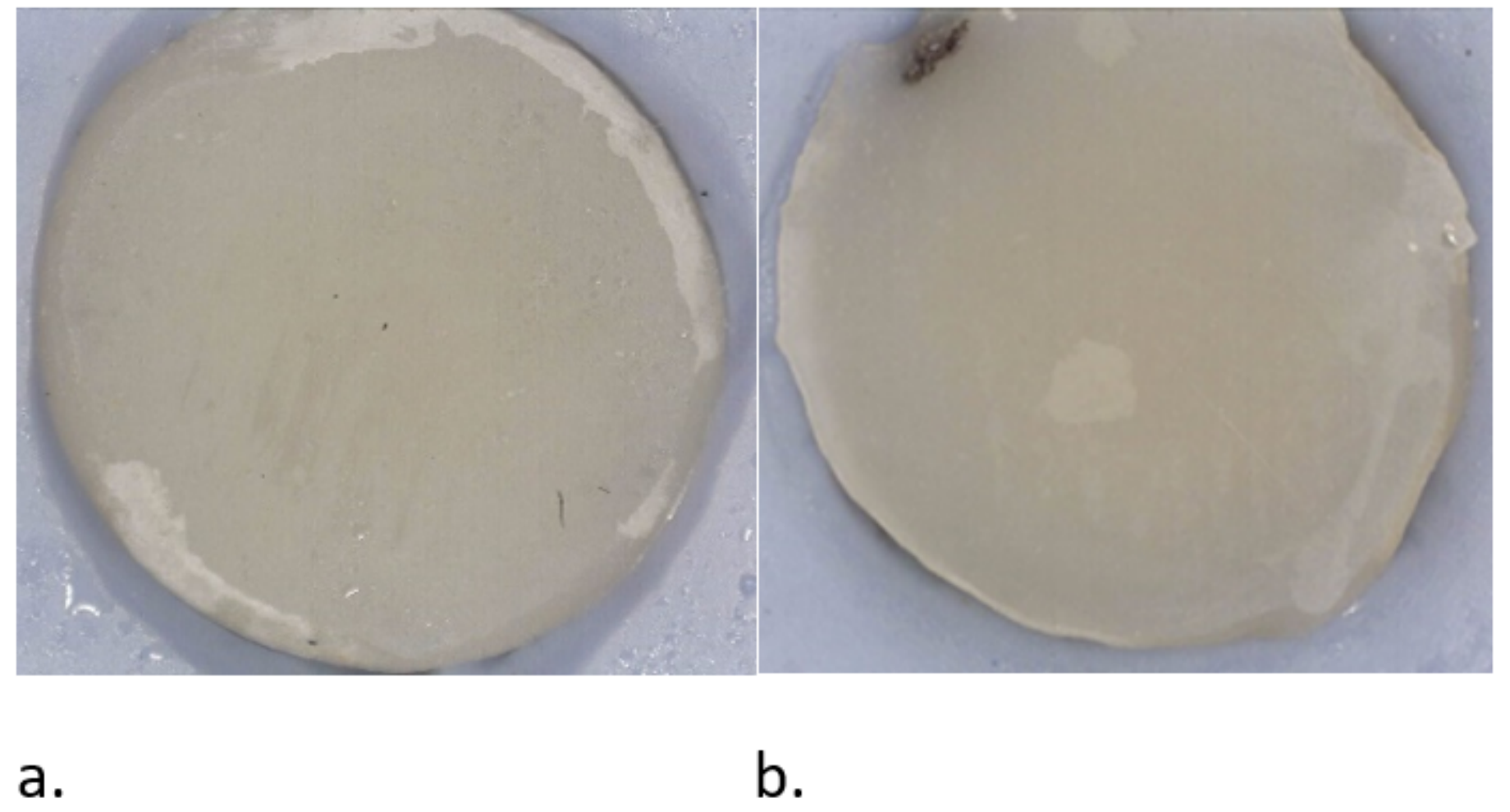

Figure 1 
Macroscopic image of nanohybrid resin composite material Filtek Ultimate: a. before acidic exposure (distilled water); b. after 14 days exposure in Coca Cola

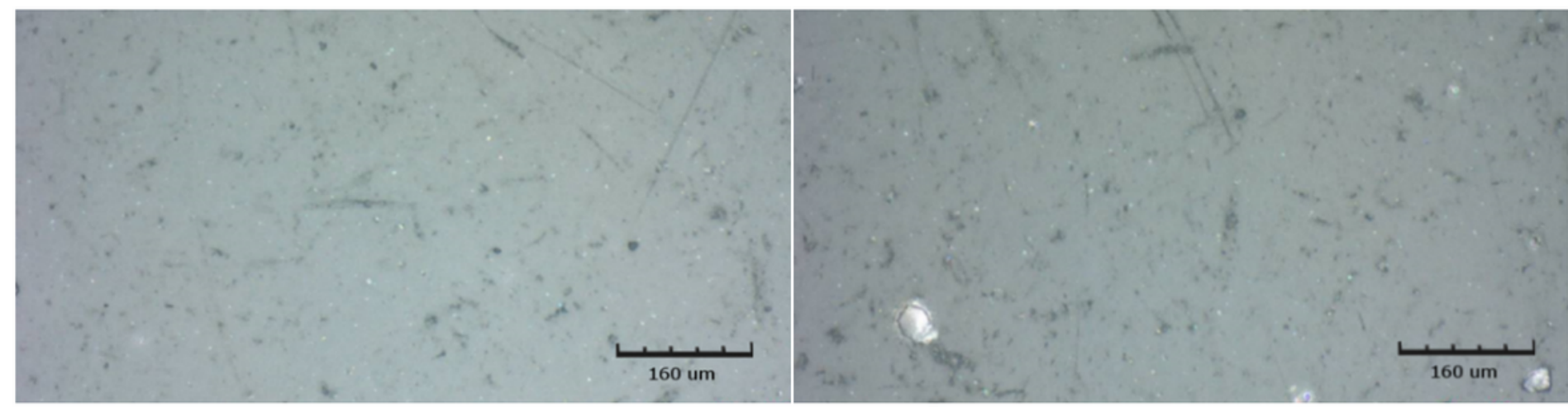

a.

b.

\section{Figure 2}

CLSM image of nanohybrid resin composite material Filtek Ultimate: a. before acidic exposure (distilled water); b. after 14 days exposure in Coca Cola

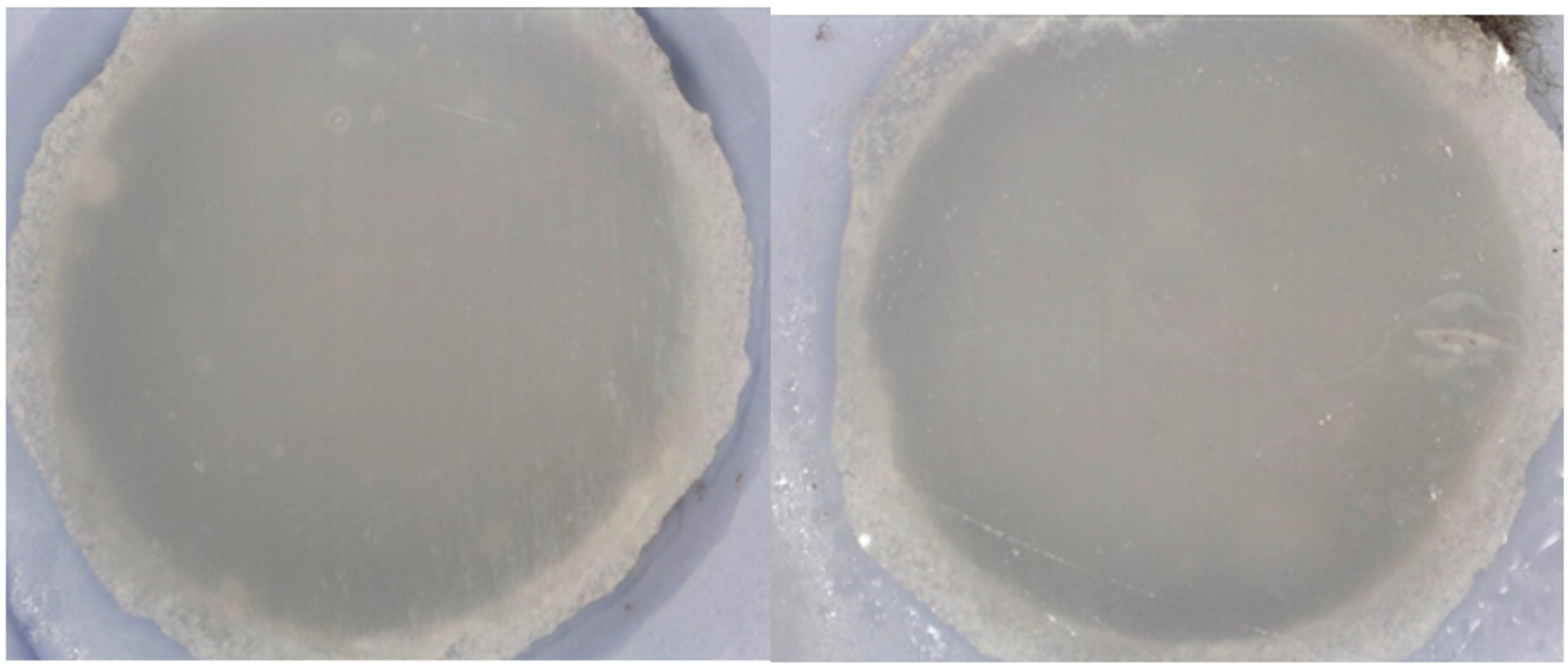

a.

b.

\section{Figure 3}

Macroscopic image of flowable nanohybrid resin composite material Filtek Ultimate Flow: a. before acidic exposure (distilled water); b. after 14 days exposure in Coca Cola 


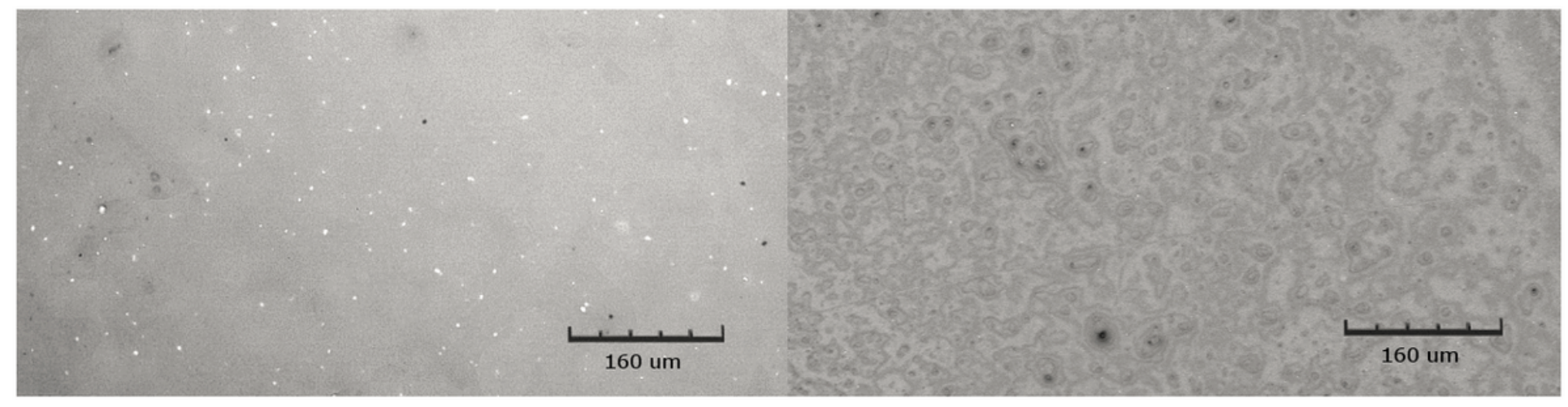

a.

\section{Figure 4}

CLSM image of flowable nanohybrid resin composite material Filtek Ultimate Flow: a. before acidic exposure (distilled water); b. after 14 days exposure in Coca Cola

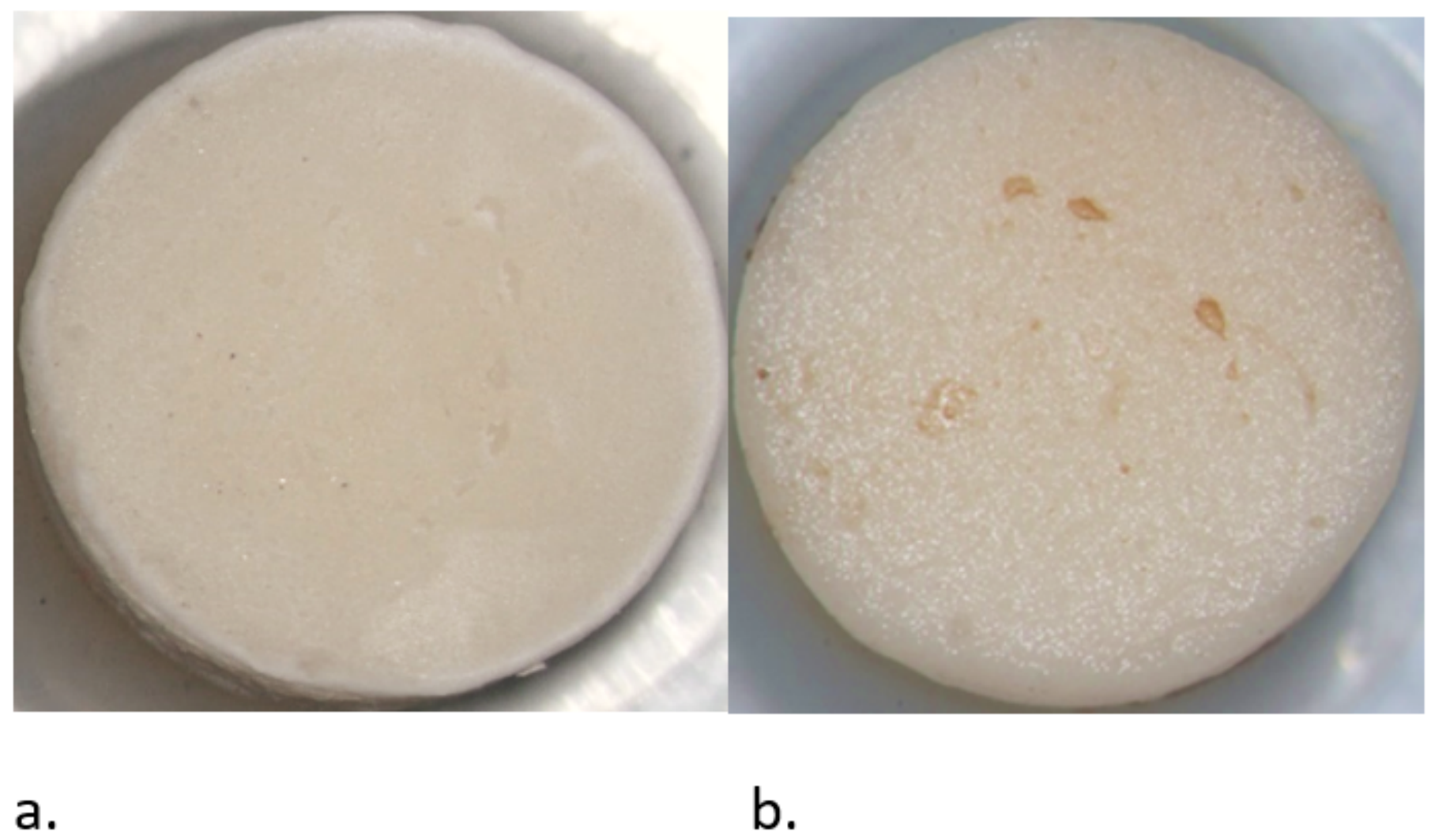

Figure 5

Macroscopic image of self curing GIC Omnifill C: a. before acidic exposure (distilled water); b. after 14 days exposure in Coca Cola 


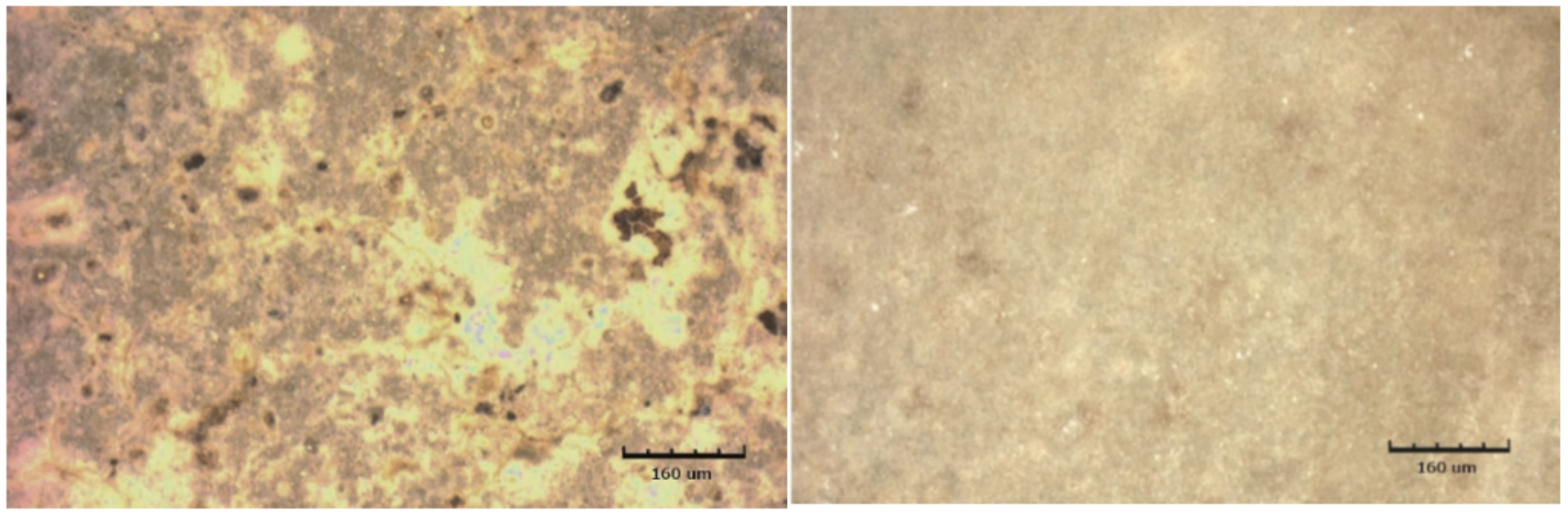

a.

b.

\section{Figure 6}

CLSM image of self curing GIC Omnifill C: a. before acidic exposure (distilled water); b. after 14 days exposure in Coca Cola

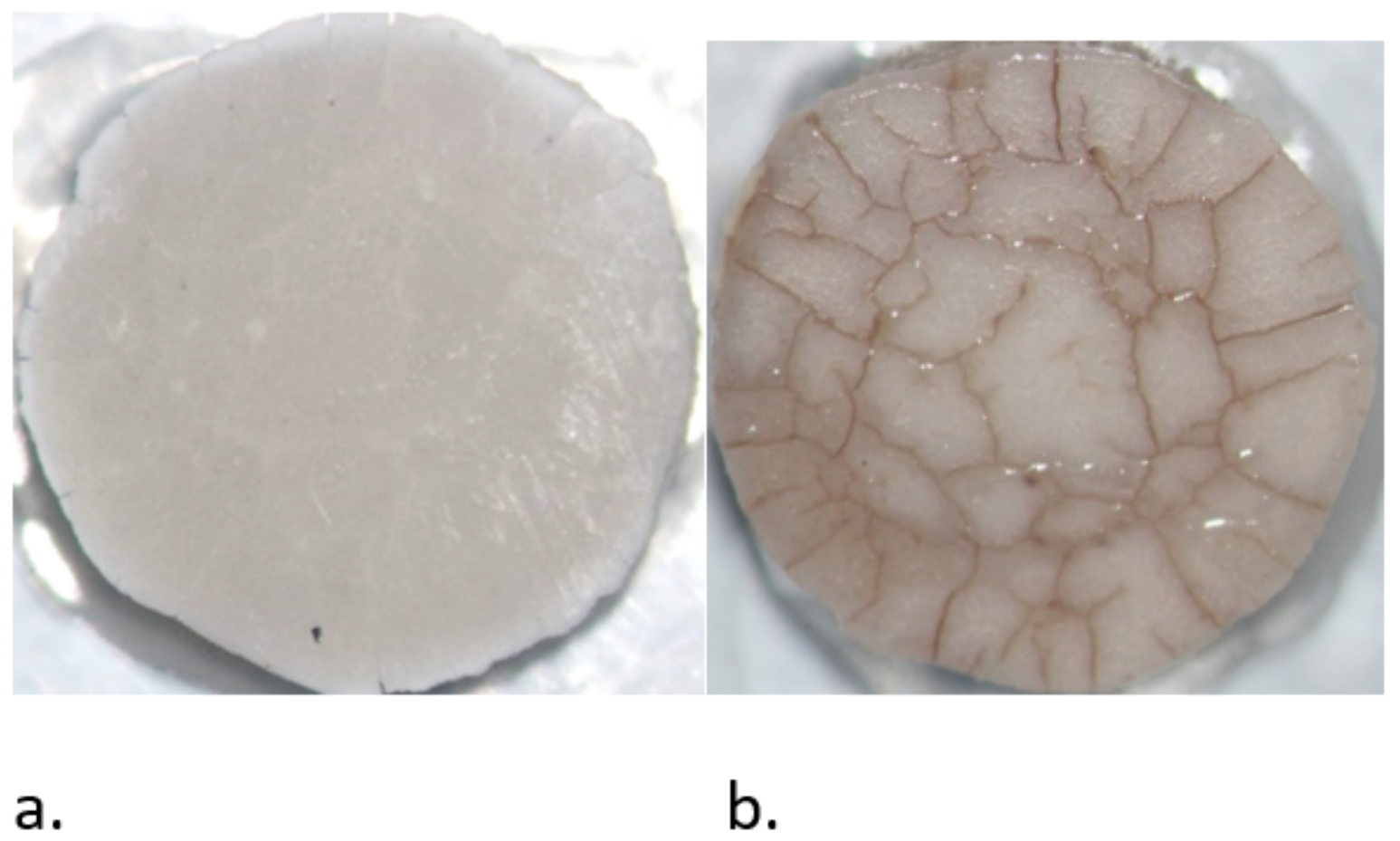

\section{Figure 7}

Macroscopic image of dual curing resin modified GIC Harvard lonoresin Fill: a. before acidic exposure (distilled water); b. after 14 days exposure in Coca Cola 


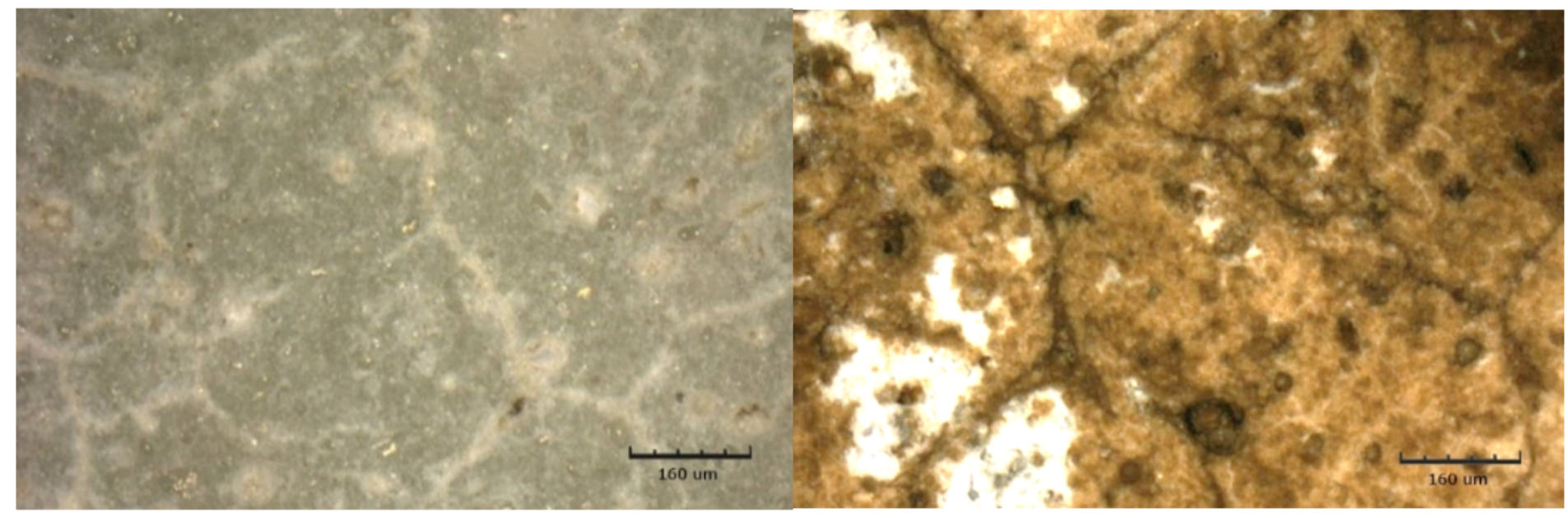

a.

b.

\section{Figure 8}

CLSM image of dual curing resin modified GIC Harvard lonoresin Fill: a. before acidic exposure (distilled water); b. after 14 days exposure in Coca Cola
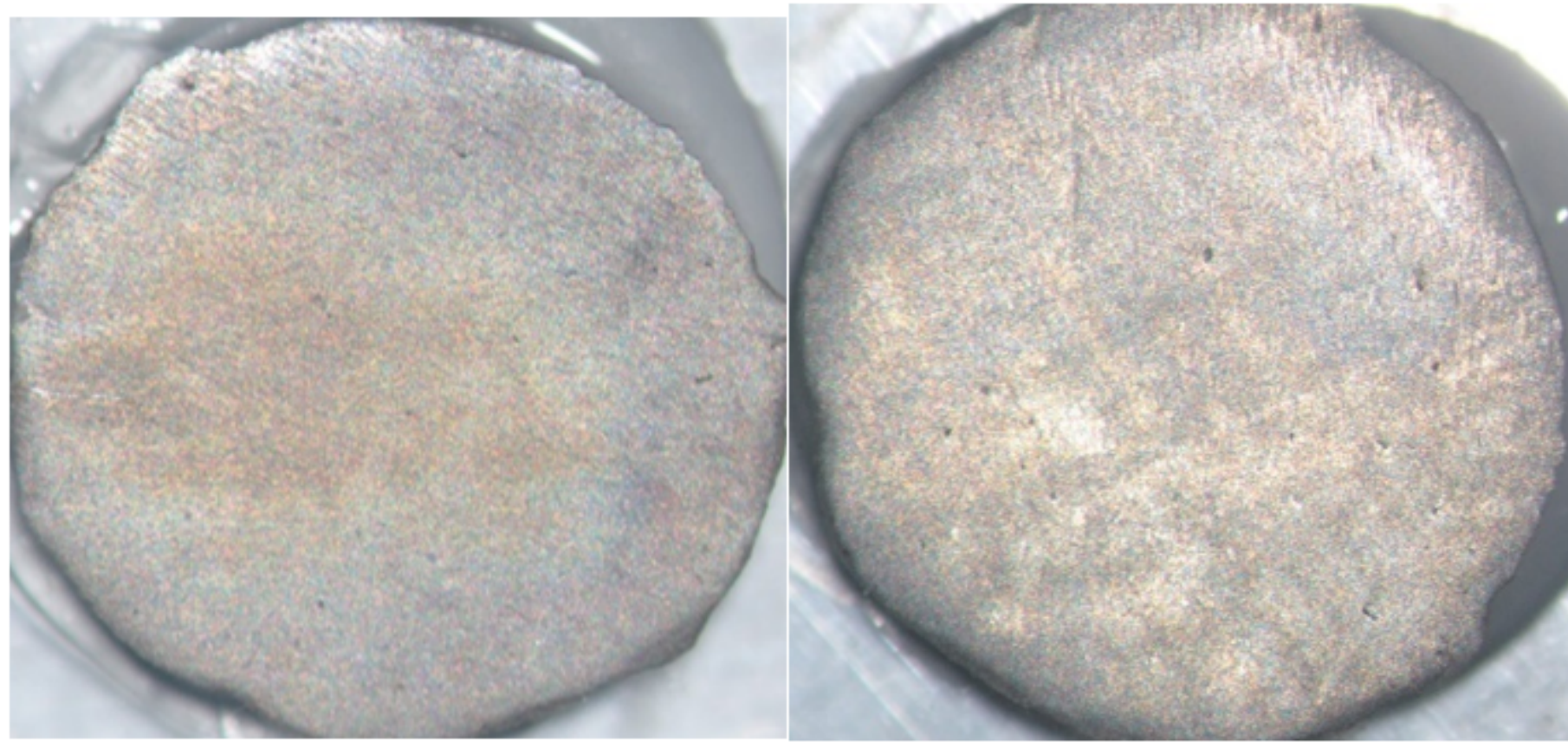

a.

b.

\section{Figure 9}

Macroscopic image of non-gamma-2 encapsulated dental amalgam SD-80: a. before acidic exposure (distilled water); b. after 14 days exposure in Coca Cola 


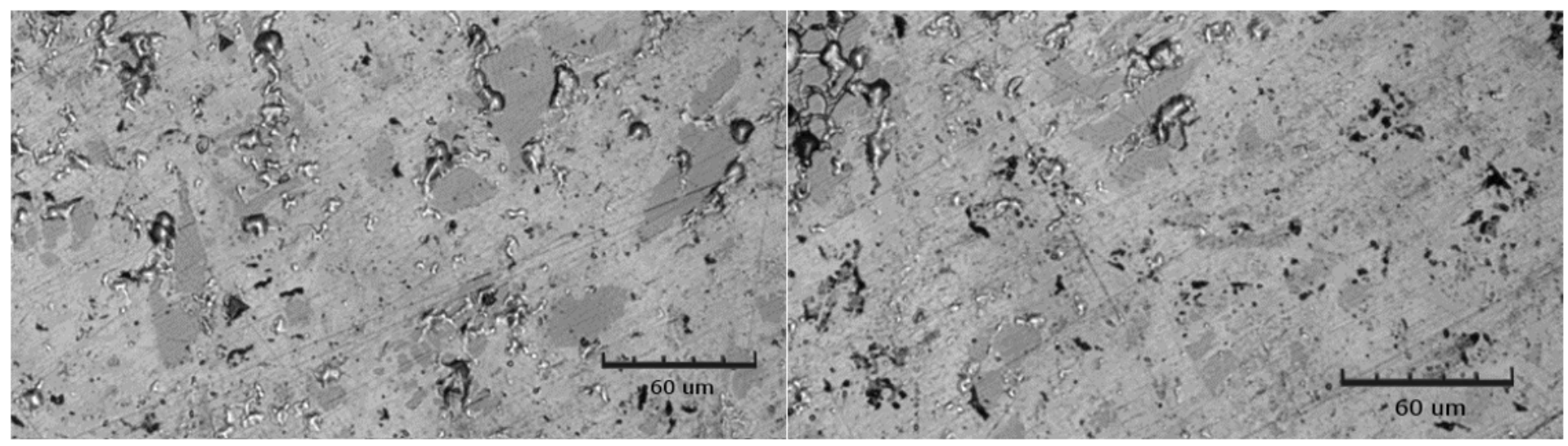

a.

b.

Figure 10

CLSM image of non-gamma-2 encapsulated dental amalgam SD-80: a. before acidic exposure (distilled water); b. after 14 days exposure in Coca Cola 